\title{
Comparison of TAP block with Bupivacaine and Magnesium as an adjunct to bupivacaine in total abdominal hysterectomy patients
}

Authors

\author{
Ankita Chandel ${ }^{1}$, Anjna Badhan², Vikas Panwar ${ }^{3}$
}

Deptt. Anaesthesia and Critical Care; IGMC, Shimla

Abstract
Present study was carried out on 60 female patients in the age group of 35 to 70 years, ASA I-II, scheduled for TAH
under subarachnoid block. The enrolled patients were divided into two groups of 30 patients in each group. We
compared magnesium in a dose of $100 \mathrm{mg}$ to bupivacaine and plain bupivacaine in TAP block and found that
magnesium adjunct to bupivacaine decreases VAS scores postoperatively, prolongs duration of analgesia,
decreased number of demands for rescue analgesia, although further studies are still required.

\section{Introduction}

Total abdominal hysterectomy (TAH) is a commonly performed major surgical procedure which results in substantial postoperative pain and discomfort. The incidence of persistent postoperative pain after TAH approaches almost $32 \%{ }^{1}$ There by a multimodal approach to postoperative analgesia after TAH is required so as to block nociceptive transmission from both the abdominal wall incision, pelvic and abdominal visceral sites.

With the advent of regional techniques, peripheral blocks remain a preferred choice for analgesia and transversusabdominis plane block (TAP) is one of the newer entry. Various drugs have been studied for prolongation of analgesia through this block. These effects are primarily based on physiological calcium antagonism, that is voltage-dependent regulation of calcium influx into the cell, and noncompetitive antagonism of N-methyl-Daspartate (NMDA) receptors. ${ }^{2}$ It prevents central sensitization from peripheral nociceptive stimulus. Evidence supporting the presence of NMDA receptors in skin $^{3}$ and muscles ${ }^{4}$ have led the use of NMDA receptor antagonists via different routes i.e. intravenous regional anesthesia, ${ }^{5}$ brachial plexus nerve blocks, ${ }^{6}$ neuraxial route $^{7}$ and intraarticular route. ${ }^{8}$ Many authors have reported that magnesium is associated with a reduced analgesic requirement and less discomfort in the postoperative period.

Whereas studies on the use of magnesium for field block are scarce, we intended to use magnesium sulphate in ultrasound guided TAP block along with bupivacaine and compared it with plain bupivacaine in patients scheduled for total abdominal hysterectomy under subarachnoid block.

\section{Methodology}

After approval by institutional ethics committee the study was carried out on 60 female patients in the age group of 35 to 70 years. Patients were ASA I-II, scheduled for TAH under subarachnoid block. The enrolled patients were divided into two groups of 30 patients in each group. The exclusion criteria included patient's refusal to block, having bleeding disorders, local infection at the site where needle for block was to be inserted, history of seizures, respiratory or cardiac diseases and 
patients on calcium channel blockers. Randomisation was achieved by computergenerated random number table

During preanaesthetic visit, the patients were explained about the study purpose, advantages and risks of procedure and instructed to demand analgesia as per requirement and informed written consent was obtained. Patients were educated about the $10 \mathrm{~cm}$ visual analogue scale (VAS) during the preoperative assessment. All the patients were kept nil orally for $8 \mathrm{~h}$ before surgery and no premedication was given. In the operation theatre, after securing 18-gauge intravenous (IV) cannula, $0.9 \%$ sodium chloride (normal saline [NS]) infusion was commenced. After establishing standard anaesthesia monitoring, baseline measurements such as heart rate (HR), non-invasive blood pressure and peripheral oxygen saturation were recorded.

All patients undergoing TAH were given SAB under all aseptic conditions in the right lateral position using 26-gauge Quincke spinal needle at L3-L4 interspace and $15 \mathrm{mg}$ of $0.5 \%$ hyperbaric bupivacaine was injected after confirming free flow of CSF. After confirmation of adequate level (T4), surgery was started. After the surgery was over and the SAB sensory level regressed to T8 dermatome, USG-guided TAP block (using SonoSite $^{\mathrm{TM}}$ Micromax machine, linear highfrequency probe, 6-13 MHz) was performed under all aseptic precautions with respective drug solutions. After draping the abdominal part between the twelfth rib bone and iliac crest with umbilicus at the centre-external oblique muscle, internal oblique muscle, transversusabdominis muscle, and their fascia were identified beneath the skin and the subcutaneous tissue.

A 23-gauge spinal needle was advanced by a USG-guided in-plane technique at the anterior axillary line and the exact location of the needle tip checked by USG. After checking the exact location of the needle tip, $1 \mathrm{~mL}$ of NS was injected to open the plane and after confirmation of hypoechoic area on USG image, the study solution of $20 \mathrm{~mL}$ was injected. Equal amount of the same solution was also injected on the opposite side using identical technique.

The patients in Group B $(\mathrm{n}=30)$ received $18 \mathrm{~mL}$ $0.25 \%$ bupivacaine $(45 \mathrm{mg}$ ) with $2 \mathrm{~mL} \mathrm{NS}$ on either side, whereas the ones in Group BM $(\mathrm{n}=30) \quad$ received $\quad 18 \mathrm{ml} \quad 0.25 \%$ bupivacaine $(100 \mathrm{mg})+1 \mathrm{ml}(100 \mathrm{mg})$ of MgSO4+1 ml N.S. each side.

Postoperatively, the patients were evaluated for pain, nausea or vomiting in the post-anaesthesia care unit at time 0 (time of completion of TAP block), 2, 4, 6, 12 and $24 \mathrm{~h}$ by an investigator blinded to the group assignment. Whenever the VAS >4, diclofenac $1 \mathrm{mg} / \mathrm{kg}$ was administered intramuscularly as a rescue analgesic and if the pain persisted, tramadol $2 \mathrm{mg} / \mathrm{kg}$ IV was administered. Patients were asked to rate average pain they experience postoperatively on a $10 \mathrm{~cm}$ VAS: No pain 0 to very severe pain 10 .

The primary outcome measure in this study was the post-operative VAS score. The secondary outcome measures included the number of supplemental analgesic requirements, duration of post-operative analgesia that is time to first analgesic request from the time of giving block.

\section{Results}

Table -1: Demographic Profile

\begin{tabular}{|c|c|c|c|c|}
\hline \multicolumn{2}{|l|}{ Parameter } & $\begin{array}{c}\text { Group B } \\
(\mathbf{n}=\mathbf{3 0})\end{array}$ & $\begin{array}{c}\text { Group BM } \\
(\mathbf{n}=\mathbf{3 0})\end{array}$ & P value \\
\hline \multicolumn{2}{|l|}{$\begin{array}{l}\text { Age }(y r s) \\
\text { Mean } \pm \text { SD }\end{array}$} & $44.6 \pm 5.86$ & $44.17 \pm 6.68$ & 0.729 \\
\hline \multicolumn{2}{|c|}{$\begin{array}{l}\text { Weight }(k g) \\
\text { Mean } \pm \text { SD }\end{array}$} & $56.13 \pm 5.21$ & $57.50 \pm 5.84$ & 0.071 \\
\hline \multicolumn{2}{|c|}{$\begin{array}{l}\text { Duration of surgery }(\min ) \\
\text { Mean } \pm \text { SD }\end{array}$} & $94.17 \pm 15.26$ & $94.67 \pm 15.64$ & 0.602 \\
\hline \multirow{2}{*}{$\begin{array}{l}\text { ASA Grade } \\
(\text { No. \%) }\end{array}$} & $\mathbf{I}$ & $24(80 \%)$ & $21(70 \%)$ & \multirow[t]{2}{*}{0.738} \\
\hline & II & $6(20 \%)$ & $9(30 \%)$ & \\
\hline
\end{tabular}


Table 2: Comparison of VAS scores

\begin{tabular}{|l|c|c|c|c|c|c|}
\hline $\begin{array}{l}\text { Group } \\
(\text { Mean } \pm \text { SD) }\end{array}$ & $\mathbf{0 ~ h r s ~}$ & $\mathbf{2}$ hrs & $\mathbf{4}$ hrs & $\mathbf{6}$ hrs & $\mathbf{1 2}$ hrs & $\mathbf{2 4}$ hrs \\
\hline Group B & $1.87 \pm 1.04$ & $1.87 \pm 1.71$ & $2.4 \pm 1.43$ & $4.53 \pm 2.62$ & $4.33 \pm 2.23$ & $3.27 \pm 1.67$ \\
\hline Group BM & $1.67 \pm 1.40$ & $2.20 \pm 2.25$ & $2.4 \pm 2.25$ & $3.33 \pm 1.77$ & $3.8 \pm 1.77$ & $1.87 \pm 1.63$ \\
\hline P value & 0.404 & 0.902 & 0.082 & 0.032 & 0.045 & 0.012 \\
\hline
\end{tabular}

Table 3: Comparison of mean duration of analgesia (time to first analgesic requirement)

\begin{tabular}{|l|c|c|}
\hline \multicolumn{1}{|c|}{ Group } & $\begin{array}{c}\text { Duration in min } \\
\text { (Mean } \pm \text { SD) }\end{array}$ & P-Value \\
\hline Group B & $397.67 \pm 92.84$ & \multirow{2}{*}{0.000} \\
\hline Group BM & $588.00 \pm 181.65$ & \\
\hline
\end{tabular}

Table 4: Comparison of total number of demands for rescue analgesia at different time intervals

\begin{tabular}{|l|c|c|}
\hline $\begin{array}{l}\text { Requirement of analgesia } \\
\text { (duration in min) }\end{array}$ & $\begin{array}{c}\text { GROUP B } \\
\text { Number (\%) }\end{array}$ & $\begin{array}{c}\text { GROUP BM } \\
\text { Number (\%) }\end{array}$ \\
\hline 120 & $1(3.3)$ & $2(6.6)$ \\
\hline $121-240$ & $1(3.3)$ & $2(6.6)$ \\
\hline $241-360$ & $8(26.6)$ & $2(6.6)$ \\
\hline $361-720$ & $28(93.3)$ & $22(73.3)$ \\
\hline $721-1440$ & $8(26.6)$ & $4(13.3)$ \\
\hline
\end{tabular}

A total number of patients enrolled during the study period were 60 , with 30 in each group.

They were comparable with each other with respect to age, weight and duration of surgery and ASA status (Table 1).

There was statistically significant decrease in VAS scores at 6, 12 and $24 \mathrm{~h}$. (Table 2)

Mean duration of analgesia was significantly prolonged in Group BM compared to Group B (Table 3). The number of requirement of rescue analgesic was more in Group B as compared to BM in the first $24 \mathrm{~h}$.(Table 4).

\section{Discussion}

TAP block is an emerging regional anaesthesia technique that provides good analgesia to the skin and musculature of the anterior abdominal wall and proved to be an effective component of multimodal analgesic regimen for abdominal procedures including large bowel resection, ${ }^{9}$ open/laparoscopic appendicectomy, ${ }^{10}$ caesarean section, ${ }^{11}$ total abdominal hysterectomy ${ }^{12}$ and laparoscopic cholecystectomy. ${ }^{13}$ Most randomized controlled trials demonstrate the efficacy of TAP block by showing some combination of reduced opioid requirement in post-operative period, low pain scores and reduced opioid-related side effects.

As we used magnesium in our study in TAP block because magnesium has drawn attention in the field of anaesthesia and pain medicine as NMDA receptor antagonist. As we know that $\mathrm{N}$ methyl-Daspartate (NMDA) receptors play a major role in central nociceptive transmission, modulation and sensitization of acute pain states. In addition to this central location, NMDA receptors are found in skin, muscle, knee joint and they play a role in sensory transmission of noxious signal. ${ }^{14}$

The primary hypothesis for analgesic property of magnesium on peripheral nerves is the surface charge theory. Akutagawa and colleagues ${ }^{15}$ showed that modulation of the external magnesium concentration bathing a nerve bundle resulted in enhancement of the nerve blockade due to LA. Mert and colleagues ${ }^{16}$ reported that a high concentration of divalent ions $\left(\mathrm{Mg}^{2+}\right.$ and $\left.\mathrm{Ca}^{2+}\right)$ attracted by the negative charge of the outer membrane surface affected $\mathrm{Na}^{+}$channel gating and could cause hyperpolarization which also support that higher concentration of magnesium (150 $\mathrm{mg}$ ) provided a more pronounced prolongation of block. When nerve fibre is 
hyperpolarized, it is more difficult to achieve the threshold level, and then resulted in nerve conduction block.

Another possible mechanism for the analgesic effect of magnesium is the voltage-dependent antagonism of NMDA receptors which lead to prevent central sensitization from peripheral nociceptive stimulation and decrease in acute pain.

So mechanism is likely direct action of magnesium on the peripheral nerve by blocking the release of excitatory neurotransmitter or by potentiating the effect of LA. ${ }^{17}$ The direct action of magnesium on the peripheral nerves is supported by the study done by Belgin Buyukakilli and colleagues, ${ }^{18}$ who found that magnesium added to bupivacaine resulted in impulse inhibition in a frog sciatic nerve.

In our study, the addition of magnesium to bupivacaine in a dose of $100 \mathrm{mg}$ has led to lower VAS pain scores, prolongation of analgesia in post-operative period, less requirement of rescue analgesia and but further studies are still required for a direct comparison of magnesium in TAP block, though we have tried to compare our results with limited data available in literature.

\section{Conclusion}

Our data supports specific action of magnesium on peripheral nerves leading to better pain scores and decrease in postoperative analgesic requirement. To summarize, the addition of magnesium in a dose of $100 \mathrm{mg}$ to bupivacaine in TAP block decreases VAS scores postoperatively, prolongs duration of analgesia, decreases number of demands for rescue analgesia, although further studies are still required to establish efficacy of magnesium as an adjunct in TAP block.

\section{References}

1. Brandsborg B, Nikolajsen L, Kehlet $\mathrm{H}$, Jensen TS. Chronic pain after hysterectomy. Acta Anaesthesiol Scand 2008;52:327-31.

2. Woolf CJ, Thompson SW. The induction and maintenance of central sensitization dependent on N-methyl-D-aspartic acid receptor activation: Implications for the treatment of post-injury pain and hypersensitivity states. Pain 1991;44:293-9.

3. Iwatsu O, Ushida T, Tany T. Peripheral administration of magnesium sulphate and ketamine hydrochloride produces hypothesia to mechanical stimuli in humans. J Health Sci 2002;48:69-72.

4. Cairns BE, Svensson P, Wang K. Activation of NMDA receptors contributes to human pain and rat afferent discharges evoked by injection of glutamate into the masseter muscle. J Neurophysiol 2003;90:2098-105.

5. Turan A, Memis D, Karamanlioglu B, Guler $\mathrm{T}$, Pamukçu Z. Intravenous regional anesthesia using lidocaine and magnesium. Anesth Analg 2005;100:1189-92.

6. Lee AR, Yi HW, Chung IS, Ko JS, Ahn HJ, Gwak MS, Choi DH, Choi SJ. Magnesium added to bupivacaine prolongs the duration of analgesia after interscalene nerve block. Can J Anaesth 2012;59:21-7.

7. Ghatak T, Chandra G, Malik A, Singh D, Bhatia VK. Evaluation of the effect of magnesium sulphate vs. clonidine as adjunct to epidural bupivacaine. Indian $\mathrm{J}$ Anaesth 2010;54:308-13.

8. Elsharnouby NM, Eid HE, Elezz ANF, Moharram AN. Intraarticular injection of magnesium sulphate and/or bupivacaine for postoperative analgesia after arthroscopic knee surgery.AnesthAnalg 2008;106:154852.

9. McDonnell JG, O’Donnell B, Curley G, Heffernan A, Power C, Laffey JG. The analgesic efficacy of transversusabdominis plane block after abdominal surgery: A prospective randomized controlled trial. Anesth Analg 2007;104:193-7.

10. Niraj G, Searle A, Mathews M, Misra V, Baban M, Kiani S. Analgesic efficacy of ultrasound- guided transversusabdominis plane block in patients undergoing open appendicectomy. $\mathrm{Br} \quad \mathrm{J} \quad$ Anaesth 2009;103:601- 5. 
11. McDonnell JG, Curley G, Carney J, Benton A, Costello J, Maharaj $\mathrm{CH}$. The analgesic efficacy of transversusabdominis plane block after caesarean delivery: A randomized controlled trial. Anesth Analg 2008;106:186- 91.

12. Carney J, McDonnell JG, Ochana A, Bhinder R, Laffey JG. The transversusabdominis plane block provides effective postoperative analgesia in patients undergoing total abdominal hysterectomy. AnesthAnalg 2008;107:2056- 60.

13. Ra YS, Kim CH, Lee GY, Han JI. The analgesic effect of the ultrasound- guided transversusabdominis plane block after laparoscopic cholecystectomy. Korean J Anesthesiol 2010;58:362- 8.

14. Lawand NB, Willis WD, Westlund KN. Excitatory amino acid receptor involvement in peripheral nociceptive transmission in rats. Eur J Pharmacol 1997;324:169-77.

15. Akutagawa T, Kitahata LM, Saito H, Collins JG, Katz JD. Magnesium enhances local anesthetic nerve block of frog sciatic nerve. AnesthAnalg 1984;63:111-6.

16. Mert T, Gunes Y, Guven M, Gunay I, Ozcengiz D. Effects of calcium and magnesium on peripheral nerve conduction. Pol J Pharmacol 2003;55:25-30.

17. Ammar AS, Mahmoud KM. Does the addition of magnesium to bupivacaine improve postoperative analgesia of ultrasound-guided thoracic paravertebral block in patients undergoing thoracic surgery. J Anesth 2014;28:58-63.

18. Buyukakilli B, Doruk N, Comelekoglu U, Camdeviren H, Gunefi S. Do adjuncts (tramadol and magnesium) potentiate impulse inhibition by a local anesthetic in isolated frog sciatic nerves. Turk J Med Sci 2006;36:201-7. 